\title{
THE EU, THE MEMBER STATES AND THE FU'TURE \\ OF PUBLIC BROADCASTING
}

\author{
CHRISTINA HOLTZ-BACHA \\ LEHRSTUHL FUER KOMMUNIKATIONSWISSENSCHAFT. UNIVERSITAET ERLANGEN-NUERNBERG
}

Resumen

La Comisión Europea ha venido ejerciendo una considerable presión sobre el sistema público de difusión. El motivo radica en que la Comisión entiende la difusión como cualquier otro servicio y aplica por tanto la regulación en materia de competencia a las cadenas de transmisión independientemente de que tengan intereses comerciales o desarrollen una función de servicio público. Contraria a esta idea, la financiación de la radiodifusión pública hace referencia a aquellas ayudas procedentes del Estado y que sólamente son permitidas en determinadas circunstancias. En los últimos años, varias cadenas privadas de difusión de diferentes países miembros de la Unión Europea se han sentido molestas por esta forma de financiación y han denunciado que las yudas estatales al servicio público de radiodifusión provocan una distorsión de la competencia. En un primer término, la Comisión se mostró reacia a intervenir pero con el paso del tiempo ha ido adoptanto una postura más comprometida $y$, finalmente, ha dejado al margen a los estados miembros aunque, de acuerdo con el Protocolo de amsterdam, tienen la competencia para determinar la función del Sistema Público de Difusión y para decidir el modo de financiación. Esta lucha persigue cambiar este sistema, pendiente de definir desde hace más de cincuenta años.

\section{Abstract}

Public service broadcasting (PSB) has come under considerable pressure by the EU Commission. This is due to the fact that the Commission treats broadcasting as a service as any other and therefore applies the competition regulation of the EC Treaty to broadcasting stations, independent of their commercial interests or public service mission. Against this background, the financing of public broadcasting is regarded as being state aids that are only allowed under special circumstances. In recent years, several commercial broadcasters from different member states filed complaints and claimed distortion of competition through state aids for public service broadcasting. At first, the Commission remained reluctant but has meanwhile adopting an active role, finally pushing aside the member states although, according to the Amsterdam Protocol, they have the competence to define the remit of PSB and to decide about its funding. This battle is about to change the broadcasting systems of the European countries where PSB has been a defining feature for more than 50 . 
The cornerstone for what only later could be called the Community's broadcasting policy was laid as early as 1974 when the European Court of Justice made its decision in the so-called Sacchi case and declared broadcasting to be a service. This can either be called a momentous decision or a trick. I don't want to say that calling broadcasting a service was necessarily a dirty trick, but the consequences are problematic and some might even say dirty. That is a consequence of the difficult construction of the EU that divides legal competence between the Union and the Member States. On the whole and referring closer to the topic at hand, the Union has far reaching competence in the field of economy, while cultural matters lie in the hands of the Member States. When it comes to broadcasting, the Union, or to be more specific, the Commission, enters a tightrope walk, and tricks are needed to prevent it from falling off the track.

The significance of the Court's decision did not really come into bearing until the Commission became active in the field of broadcasting. That happened in the early 1980s when the Commission prepared its Television without Frontiers Green Paper which was to become the Television Without Frontiers (TWF) Directive in 1989. The Green Paper was published in 1984. It was not by accident that this happened at a time when the broadcasting landscape in most West European countries started to change dramatically. The introduction of commercial channels ended the monopolies of public broadcasting and forced it into a competition that public broadcasting had not experienced before.

Regarding broadcasting as a service had serious consequences: It provided the Commission with a legitimation to deal with broadcasting. Services are subject to the common market regulation which is to ensure the freedom of movement for goods, services, people and capital. The dominant paradigm of the common market is to provide for undistorted competition. What also plays a role here is the fact that decisions affecting the common market are taken by a majority voting in the Council rather than by unanimous agreement.

With regard to public service broadcasting, we can distinguish two lines of argument which, however, are interrelated. On the one hand, the idea and function of public service broadcasting is under review considering the new multitude of outlets. In this context PSB is assigned the role of a guarantor of diversity. On the other hand, the debate focuses on the competition between the two broadcasting systems. Commercial channels in particular claim equal chances, and, thus, question the obviously privileged position of their public service counterparts. Various actors are involved in the debate, with the European Parliament taking a stance that is more favorable to public service broadcasting while the Commission, constrained by the competition articles of the Treaty, seems to have moved closer to the side of the commercial broadcasters.

Although the European Court of Justice declared broadcasting a service as early as 1974 and, thus, opened the way for the Community to deal with broadcasting, the question of competence remained a permanent and controversial issue when first the Green Paper and then the Draft Directive were discussed since the mid-1980s. At first as a reaction to the decision of the European Court of Justice in the Sacchi case and from then on, again and again, some Member States poin- 
ted to the cultural character of broadcasting and raised doubts about the right of the Community to become active in the field of broadcasting. Denmark for example refused to accept the 1989 TWF Directive because it disputed the competence of the Community for the regulation of broadcasting.

The question of competence flared up again in the early 1990s and made public service broadcasting "one of the most controversial and pressing issues to be dealt with by the European Commission in the audiovisual sphere" (Ward, 2003, p. 234). The cause for this development was the discussion about the nature of the financing of the public channels. All Member States support public service broadcasting in one way or the other through public funds. This raised the question as it relates to the applicability of the state aid articles of the Treaty. According to Article 87, any state aid which may distort competition is incompatible with the common market. Article 88 entrusts the Commission the review of all aid systems and to propose the Member States any appropriate measures to ensure the functioning of the common market. Some aids may nevertheless be compatible with the common market which are listed in Article 87. Among those are aids to promote culture and heritage conservation as long as such aid does not affect competition in the Community to an extent that is contrary to the common interest (Treaty, Article 87(2)(d)). Finally, the provisions on state aids are confronted with Article 86(2) which allows to exempt undertakings entrusted with the operation of services of general economic interest from the competition rules if the application of these rules obstruct the performance of the particular tasks assigned to them.

Against this background it has to be decided whether broadcasting fees or any other financial support of public broadcasting are to be regarded as state aid in the sense of the competition articles of the Treaty. If broadcasting fees are understood as state aids, it is still the question whether these could be compatible with the common market under the provision that public broadcasting promotes culture and heritage conservation (Art. 87(3)(d)). Finally, it has to be examined whether public broadcasting stations are "undertakings entrusted with the operation of services of general economic interest" and should, therefore, be excluded from competition regulation because this would endanger the performance of their particular task. So, firstly, if broadcasting fees and other forms of support for public service broadcasting are regarded as state aids that, secondly, could affect competition on the broadcasting market, this puts the financing and thus the whole system of PSB financing under threat. At the same time it becomes clear why this has become a controversial and pressing issue in European audiovisual politics.

When several commercial broadcasters filed complaints and claimed distortion of competition through state aids for public service broadcasting, the Commission at first remained reluctant but was finally urged by the European Court of First Instance to deal with the matter in more detail. A 1998 discussion paper by the Competition Directorate (GD IV) was meant to give guidelines for assessing the compatibility of PSB funding with Community Law. This proposal, however, caused outrage, particularly because of its ideas concerning the mixed-funded broadcasters. The paper suggested that some entertainment and sports programs were not to be understood as comprised by the public service remit and, thus, could not be financed out of the broadcasting fee or other state money. 
At last, the European Council at its Amsterdam summit in June 1997 came to help the public broadcasters by deciding upon a protocol that was annexed to and, therefore, became part of the new Amsterdam Treaty. The introductory part of the Protocol stressed that "the system of public broadcasting in the Member States is directly related to the democratic, social and cultural needs of each society and to the need to preserve media pluralism" and thus attributed a pivotal role to PSB. Furthermore, the Protocol reaffirmed "the competence of Member States to provide for the funding of public service broadcasting insofar as such funding is granted to broadcasting organisations for the fulfilment of the public service remit as conferred, defined and organised by each Member State, and insofar as such funding does not affect trading conditions and competition in the Community to an extent which would be contrary to the common interest, while the realisation of the remit of that public service shall be taken into account" (Protocol..., italics added). Thus, the Protocol does not contain any provisions on whether the funding of PSB is to be defined as state aids. However, even if the funding was to be understood as state aids, against the background of the Protocol PSB funding could not easily be considered incompatible with the common market.

In addition, the provisions of the Protocol seemed to be in line with Article 128 that was newly adopted with the Maastricht Treaty. This article (now: Article 151) limits the competence of the Union in the cultural sector to supportive measures. Since paragraph 2 of the article explicitly mentions the audiovisual sector, it was interpreted as restricting the competence of the Union in respect to broadcasting (cf. Dörr, 1999, p. 77).

In June 1999 and thus even before the Amsterdam Treaty came into force, the Council passed a resolution reaffirming the "significance of public service broadcasting for ensuring democracy, pluralism, social cohesion, cultural and linguistic diversity" in the European Union. The wording of the resolution even seems to suggest a guarantee for further development of public broadcasting by stressing its "important role in bringing to the public the benefits of the new audiovisual and information services and the new technologies". At the same time, the resolution explicitly mentions that public service broadcasting must have a chance for the development and diversification of activities in the digital age (Council, 1999).

Again the proponents of PSB breathed a sigh of relief when the Commission released its Communication on the application of state aid rules to public service broadcasting in November 2001 (Communication from the Commission, 2001). Although the title of the Communication made clear that the Commission did not want to reopen the discussion about the definition of PSB financing as state aids, the text seemed to respect the Amsterdam Protocol and the 1999 Council resolution. Rather than outlining an active role of the Commission, the Communication served to develop a consistent and transparent procedure for assessing whether these state aids are compatible with the common market or might distort competition. Against this background the Commission attributed the public stations "a clear economic relevance" but at the same time admitted that public service broadcasting "is not comparable to a public service in any other economic sector". In accordance with the Amsterdam Protocol, the Communication confirmed that the definition of the public service remit falls under the competence of the Member States. This could be a "wide" definition but is expected 
to be as precise as possible and it might include services that are not programs in the traditional sense such as online-information services, as long as they follow the remit. The task of the Commission was restricted to verifying whether the Member States respect the provisions of the Treaty when defining the public service mandate.

In addition, the Communication laid the choice of the financing scheme for public service broadcasting into the hands of the individual Member States. At the same time however, it put up transparency requirements that clearly separate public service activities and non-public service activities according to the Community's Transparency Directive. Separate accounting for public service and non-public service activities is to provide the Commission with the information that is necessary to decide whether the funding is disproportionate and might affect competition.

While the 2001 Communication of the Commission seemed to be in line with the Amsterdam Protocol and the 1999 Council resolution by attributing the definition and the choice of financing to the Member States, several cases that the Commission had to deal with recently have led to a reshuffling of cards, and, thus, a shifting of power. These cases were brought forward by commercial broadcasters from different countries who claimed distortion of competition through state funding of public service broadcasting and at the same time began to ask critical questions about the limits of the public service mandate. Because the Commission treated the first complaints dilatory, it was even urged by the European Court of First Instance to deal with them and examine each case according to the state aid rules of the Treaty. As a consequence, the definition of the public service remit and with it the transparency requirements have become the focus of discussion. At the same time, the Commission's attitude towards public service broadcasting has obviously undergone a change to a more critical stance which puts the future of PSB at risk.

Although there is still some resistance on the part of the Member States, the Commission has in any case qualified funding of public service broadcasters as state aids. Therefore, any examination of particular cases is to determine whether the amount of the funding corresponds to the public service remit. In this context, the Commission seems to have moved from allowing a wide definition of the mandate to a more narrow concept since the online activities of public broadcasters have come under scrutiny which were explicitly mentioned in the 2001 Communication. Moreover, by insisting upon applying the separate accounting rules of the Transparency Directive, the Commission takes for granted that public broadcasters follow non-public service activities beyond their public service activities. All of this seems to indicate that the Commission is about to snatch the competence for broadcasting from the Member States.

Interestingly, the stance of the Commission on PSB now also stands in contrast to the position of the European Parliament. While the Commission treats broadcasting according to the competition rules of the Treaty and only pays lip service to the cultural aspects of broadcasting, the Parliament has repeatedly stressed the particular function of public service broadcasting and its role as a cultural factor for which special conditions should apply. As early as 1996, the resolution of the European Parliament on public service television criticized the "economic slant" of the Commission's po- 
licy on the information society and pointed out that cultural goods, and particularly cinema and TV programs, could not be treated like other products. Therefore, the resolution stressed, broadcasting structures should not be subsumed under government-financed institutions. (CF. European Parliament, 1996a)

In its "Resolution on the role of public service television in a multi-media society" that was based on a report by Carole Tongue on behalf of the Committee on Culture, Youth, Education and the Media (Committee on Culture..., 1996) and passed in 1996, the Parliament called on the Commission to make the greatest possible use of the special provision of the competition rules as laid down in Article 87(3) (former article 92(3)) to ensure the national financing systems that support radio, television and the press. At the same time, the resolution proposed to make adjustments in the Treaty as soon as possible to allow the Union to "develop a positive policy on PSB recognising its crucial importance in building national and European citizenship rather than a policy that is based exclusively on exceptions to provisions on competition and internal market policy" (European Parliament, 1996b; italics added). The Parliament did not make any concrete proposals on how these adjustments should look like. However, claiming a "positive policy" can only mean that the Parliament thought of a regulation that would allow the Commission to acknowledge the cultural aspects of broadcasting.

Not only that the Commission has never taken up this recommendation, over the years it has even turned further away from the Parliament's position that insisted upon a special function and thus a special treatment of public broadcasting. In fact, under increasing pressure by complaints filed by commercial broadcasters, the Commission had to give up its rather reactive policy on the financing of PSB and adopted an active role that focused on the application of the competition regulation of the Treaty. Its recent actions and decisions demonstrate that the Commission is about to take the competence out of the hands of the Member States as it was determined in the Amsterdam Protocol and confirmed in the 2001 Communication of the Commission.

Treating broadcasting according to the economic perspective of the Treaty only jeopardizes the future of PSB which for more than 50 decades has been a defining feature of the West European media landscape and has also served as a model for the transformation of broadcasting in the newly developed democracies of Eastern Europe. The problem lies in the economic focus of the EC Treaty which of course is a consequence of the history of the European Economic Community that only recently embarked on a broader political path. Defining broadcasting as a service, allowed the Community to deal with broadcasting, although only under the economic perspective. Even though some cultural aspects have made their way into the Treaty in the meantime, the competence for cultural matters rests with the Member States which they guard and defend jealously. As long as the Member States do not transfer cultural competence to the Community, the Commission, whose role is to safeguard the Treaty, can only apply economic rules to broadcasting. This, however, puts public service broadcasting at risk. An alternative solution to the problem would be that the Member States, by insisting upon their competence to define the PSB remit and to secure adequate financing, put the Commission back into its place as far as broadcasting is concerned and save the traditional European broadcasting model. 


\section{REFERENCES}

- Committee on Culture, Youth, Education and the Media. (1996). The future of public service television in a multi-channel digital age. [http://www.poptel.org.uk/carole-tongue/pubs/psb_b.html].

- Communication from the Commission on the application of State aid rules to public service broadcasting. (2001). Official Journal of the European Communities, (C320), p. 5-11.

- Council. (1999, February 5). Resolution of the Council and of the representatives of the governments of the Member States, meeting within the Council of 25 January 1999 concerning public service broadcasting. Official Journal of the European Communities, (C30), p. 1.

- Dörr, D. (1999): Europäische Medienordnung und -politik. In Hans-Bredow-Institut (Ed.), Internationales Handbuch für Hörfunk- und Fernsehen 98/99 (pp. 71-93). Baden-Baden: Nomos.

- European Parliament. (1996a, October 28). Resolution on 'Europe and the global information society - Recommendations to the European Council' and on a communication from the Commission of the European Communities: 'Europe's way to the information society: an action plan'. Official Journal, (C 320), pp. 164-179.

- European Parliament. (1996b, October 28). Resolution on the role of public service television in a multi-channel society. Official Journal, (C 320), pp. 180-187.

- Protocol on the system of public broadcasting in the Member States. Protocol annexed to the Treaty establishing the European Community (Treaty of Amsterdam).

- Ward, D. (2003): State aid or band aid? An evaluation of the European Commission's approach to public service broadcasting. Media, Culture \& Society, 25, 233-250. 
